\title{
TEACHING ENGLISH WITH STORY TELLING METHOD IN EARLY CHILDHOOD EDUCATION TEACHERS
}

\author{
Arsyi Rizqia Amalia \\ Muhammadiyah University of Sukabumi \\ e-mail:arsyirizqiaamalia@ummi.ac.id
}

\begin{abstract}
The importance of English has an impact on the needs of future generations to learn English from an early age especially in Early Childhood Education and vocabulary is an important component that can support the mastery of all four language skills. Facing the difficulty of learning vocabulary, a method that is appropriate for the age of child development is needed. One of methods that could be used is story telling. The research method used in this research is qualitative descriptive. The sample in this study was six early childhood education teachers in Sukabumi. Data collecting techniques were presentations and questionnaires. The presentations were held twice, in front of peers of early childhood education teachers and in front of students of early childhood education. After presentation, the questionnaires were conducted related to the implementation of the story telling method to the teacher. Based on the data collected, Teaching English with Story Telling Method give a good response with indicators shows that the content of the story, the properties used, the variety of vocabulary taught, moral values based on the stories and the ability of delivering the English vocabulary were good and suitable with the age of early childhood education.
\end{abstract}

Keywords: storytelling, early childhood education

\section{Introduction}

Language is the key of life, with language people can interact each other. There are many definitions of language which is stated by some experts, but basically most of them agree that language is a means of communication between members of society in the form of symbols that have their own peculiarities. Learning language is an important thing in order to be able to survive in a social environment. In Indonesia, we can find a diversity of languages that will not be found in other countries, such as regional languages, national languages and foreign languages. Ellis, Gass, and Slinker in Djonhar (2012) state that in Indonesia, bahasa Indonesia is placed as second language, because the first language is regional or also called local language, while the position of other languages such as English is a foreign language in Indonesia. The term foreign language refers to a non-native language which is learned and used by non-native speakers in the environment of non-native language. 
English as a foreign language has an important position in Indonesia. As the number one international language in the world, everyone is required to be able to master English. English is also used in almost all sectors of life, for example in industrial, economic, or education sectors. The focus in this study is English in the education sector. In formal education, English is introduced and taught from elementary school to university level.

Under five years old is also called the golden age because at that age children are considered able to absorb what they receive quickly. This is related to the theory presented by Blackledge and Creese (2010) that "children can learn more than one language. Indeed, for children in the world, being bilingual or multilingual is everyday reality". It is important for early childhood teachers to be able to maximize these golden times by providing the best intake in order to have a good impact.

There are four language skills that must be mastered, such as speaking, writing, listening and reading. The teaching of English in early childhood does not cover the four domains specifically yet, but rather to master the basic language first, it is vocabulary mastery. Vocabulary is an important component that can support the mastery of all four language skills. Vocabulary is suitable for learning by children because there are no rules or formulas that need to be learned like when we face grammar. Introducing vocabulary for children entering the golden age can help their interest in learning English in the future.

Kamil and Heibert (2005) stated that "vocabulary can be generically defined as knowledge of words or word meaning. They stated that vocabulary learning is the basis of language and without vocabulary, anyone cannot learn any language. According to Harmer (2007), "in vocabulary learning, learners will be constantly tested to find out their level of improvement in vocabulary knowledge". Based on the statements, it can be concluded that if the learners do not have sufficient vocabulary knowledge, they will have difficulties in learning a language.

The importance of learning vocabulary is conveyed by Martin-Chang \& Gould (2008) which stated that one of the most important factors that affect language learning is vocabulary and it is agreed that vocabulary helps language learning improvement. The author agrees with the statement because a person's language skills will depend heavily on his vocabulary mastery.

Emphasizing the importance of vocabulary, Thornbury (2002: 13), said "Without Grammar very little can be conveyed, without vocabulary nothing can be conveyed." It was true what Thornbury said that even though our grammar skills were good, it would be useless if we don't master vocabulary. The same thing was also expressed by Stahl and Nagy (2005) who said: "A person who knows more words can speak, and even think, more precisely about the world." They revealed on the basis of comparisons between people who understood vocabulary with those who do not understand vocabulary.

The introduction of foreign language vocabulary will greatly influences the mastery of one's language, Zhang and Anual (2008) studied the correlation of vocabulary knowledge in foreign language and the result showed that there is a significant strong relationship between foreign language learning and vocabulary knowledge. Although the vocabulary is closely related to the ability to speak 
English and it is known as the basic of a language, learning vocabulary is not easy. Stahl and Nagy (2006) stated that "vocabulary learning is a difficult process, because students need to be motivated in vocabulary learning, engage in vocabulary instruction, meet vocabulary learning standards to pursue the required accomplishment".

The difficulty of studying vocabulary has to become a challenge for language learners since when they could face it, they will master the language. The fact shows that the difficulty of studying vocabulary occurs not only in young learners but also those who have long studied English. Facing the difficulty of learning vocabulary, a method that is appropriate for the age of learner's development is really needed. In teaching young learners, the uses of method and media have a great role in engaging students' interest so they can learn anything easily. There are so many teaching methods that can be use in teaching vocabulary for young learners, and one of methods that could be used is story telling.

\section{Method}

Research methodology is a science of studying how research is to be carrying out. Essentially, the procedures by which researcher goes about their work of describing, explaining and predicting phenomena are called research methodology. The research methodology used in this research is qualitative descriptive. The sample in this study was six early childhood education teachers whom are selected by purposive sampling. Purposive sample is a non-probability sample that is selected based on characteristics of a population and the objective of the study. Purposive sampling is also known as judgmental, selective, or subjective sampling. The sample of this research is selected based on some characteristics such as they are teacher in early childhood education located in Sukabumi and they have same educational background. In this research, the teachers selected were graduated from high school and they are under graduated students in Early Childhood Education department.

This six early childhood education teachers come from six different schools in Sukabumi, and here is the data:

Table 1. Teacher Identity

\begin{tabular}{|c|l|c|}
\hline $\begin{array}{c}\text { Initial } \\
\text { Name }\end{array}$ & \multicolumn{1}{|c|}{ School } & Length of Teaching \\
\hline NA & RA Daarul Falaah & 1 year \\
\hline YA & RA Attaufiqurrahman & 8 years \\
\hline LL & TK Harapan & 3 years \\
\hline AD & PAUD Al-Baaqii & 1 year \\
\hline SA & TK Islam Marjanul Qolbi & 2 years \\
\hline AN & TK IT Al-Alawi & 10 months \\
\hline
\end{tabular}


Data collecting techniques in this research were from presentations and questionnaires. The procedure of this research starts from researcher give materials about the characteristic of storytelling, for example how to make a story that suitable for early childhood education, how to presenting the story, how to use the properties effectively, etc. After giving the materials, teachers start to make their own story which contained vocabularies for children, the story is written in English and Bahasa Indonesia. In this process, the researcher guide the teachers and check the English used in the story. In the next meeting, teachers are allowed to make their own properties for presenting the story. After those steps are done, teachers have to prepare their selves for presentation.

The presentations were held twice, first presentation is done in front of peers of early childhood education teachers and it is scored by researcher as an English lecturer. The second presentation is in front of the students of early childhood education and it is scored by teacher's colleague in the school. Both researcher and teacher who scoring the presenter teacher have the same scoring rubric, it is related to some points such as: the suitability of the story content with early childhood age, the creativity of properties/media used, teachers ability to use the media effectively and efficiently, teachers ability in teaching English vocabulary based on the story, the variety of vocabulary taught, engaging students to be active in learning, submitting moral values based on the stories presented, teacher's English language skills (vocabulary and pronunciation), teacher's confidence, suitability of how to deliver to the early childhood age, and the benefits of the activities for early childhood education students. The instrument used for scoring the implementation of the story telling method in teaching English vocabulary was a questionnaire.

\section{Findings and Discussion}

In this research there are some activities, at the beginning, researcher give materials about the characteristic of storytelling, for example how to make a story that suitable for early childhood education, how to presenting the story, and how to use the properties effectively. This activity was done well since class discussion between the teachers and researcher done actively. Some teacher asked about how to make properties that easy to make and cheap and how to face the nervous in teaching English (afraid to make mistakes). Those questions stated relate to the teacher anxiety in teaching English to the students, even though they already know the students ability but they still afraid to make mistakes especially in pronouncing the vocabulary.

After the materials delivered, researcher asked teachers to start making their own story which contained English vocabularies for children. At the beginning, researcher asked to teacher to make story in English, but the teachers were not confidence and it took so many times without any progress until they asked if they were allowed to use Bahasa Indonesia. Right after, the researcher allowed teachers to make a story in Bahasa Indonesia first, and it supposed to be translated to English. Finally the progress in seen, teachers could make a story well and they 
started to translate it to English with dictionary. In this process, the researcher guide the teachers and check the English used in the story.

In the next meeting, teachers are allowed to make their own properties for presenting the story. There are some characteristic of the properties that could be made, first the basic materials suppose to be easy to find in our environment, it has to be safety for children and teacher should used their creativity to make properties by their selves without any help. After those steps are done, teachers have to prepare their selves for presentation.

After the properties were made, teachers will deliver their story in two opportunities, first presentation is done in front of peers of early childhood education teachers and it is scored by researcher as an English lecturer. In this opportunity, teachers had to delivery their story one by one and other teachers act as students in the class so they are allowed to ask anything to the presenter. Teachers could used two languages, that is English and Bahasa Indonesia but all vocabulary which are taught will be presented in English. For example: one day, Mr. Rabbit (ada yang tahu apa itu rabbit? Rabbit is kelinci) went to his garden (siapa yang tahu garden itu apa? Garden is kebun) to pick some carrots (siapa yang tahu bahasa Indonesianya carrot apa? Carrot is wortel) what the colour of carrot? (Carrot warnanya apa? Apa bahasa Inggrisnya oren/jingga? That is orange) that are ready to be harvested. So, in presenting the story there will be many vocabulary presented started from each figure (human, animal, etc), setting (place: garden, village, river, etc), or characteristics (colours, size, shape, etc). After all of teachers done with their story telling, other teachers are allowed to give any comment or advice to other teacher performances to make their story telling better.

The second presentation was done in front of the students of early childhood education and it was scored by teacher's colleague in the school. In this opportunity, every teacher presenting the story in the school where they are teaching, in front of their own students whom they meet every day in their teaching activity. Teachers still could used two languages, that is English and Bahasa Indonesia but all vocabulary which are taught will be presented in English. Based on interview with teachers, first presentation is more difficult than the second one, the reason is because they have to face other teachers who may be more experiences or smarter than them. Both presentations is scored by the same scoring rubric. This scoring rubric used to identify the activities of teaching English with storytelling method in early childhood education teachers and its influence both for the story made, for teachers and also for students.

Based on the data collected, Teaching English with Story Telling Method give a good response with indicators below: 
Table 2. Teaching English with Story Telling Score

\begin{tabular}{|c|c|c|c|}
\hline No & Criterion & Score & Category \\
\hline 1 & $\begin{array}{l}\text { The suitability of the story content with early } \\
\text { childhood age }\end{array}$ & 4,67 & Very Good \\
\hline 2 & The creativity of properties/media used & 4,33 & Good \\
\hline 3 & $\begin{array}{l}\text { Teachers ability in using the media effectively and } \\
\text { efficiently }\end{array}$ & 4,00 & Good \\
\hline 4 & $\begin{array}{l}\text { Teachers ability in teaching English vocabulary } \\
\text { based on the story }\end{array}$ & 4,33 & Good \\
\hline 5 & The variety of vocabulary taught & 3,80 & Good \\
\hline 6 & Engaging students to be active in learning & 4,67 & Very Good \\
\hline 7 & $\begin{array}{l}\text { Submitting moral values based on the stories } \\
\text { presented }\end{array}$ & 4,33 & Good \\
\hline 8 & $\begin{array}{l}\text { Teacher's English language skills (vocabulary and } \\
\text { pronunciation) }\end{array}$ & 4,17 & Good \\
\hline 9 & Teacher's confidence & 4,5 & Good \\
\hline 10 & $\begin{array}{l}\text { Suitability of how to deliver English materials to } \\
\text { the early childhood age }\end{array}$ & 4,5 & Good \\
\hline 11 & $\begin{array}{l}\text { Benefits of the activities for early childhood } \\
\text { education students }\end{array}$ & 4,67 & Very Good \\
\hline
\end{tabular}

The suitability of the story content with early childhood age gains a very good category with indicator that teachers make a story with anything real in children environment, keep the simplicity and use vocabulary that is suitable for children. The creativity of properties/media used gain a good score since teachers make their own properties to use in story telling activity so they are able to use the properties/media effectively and efficiently. Teachers ability in teaching English vocabulary based on the story gain good category and it is relevant with the variety of vocabulary taught which are vary and it is delivered well with interesting activities.

Teacher could engage their students to be active in learning well since the students are enthusiasm and feel interest with the story, so while the story is presented every students gave their eyes on the teacher who presented the story. Moral value is a good point that should be submitted in a story, and teacher could submit moral values based on the stories presented well. Over all, teacher's English language skills (vocabulary and pronunciation), teacher confidence and suitability of how to deliver English materials to the early childhood age gain good categories which are mean that teacher could using the story in teaching English activities well. Story telling has huge benefits for early childhood education students because they can learn something while doing something interesting in the same time. 


\section{Conclusions and Suggestions}

Teaching English for a very young learner has a big challenge especially for the teachers; every learning material that we give should follow the characteristic of the students. Students under seven years old like anything that is not too serious and it has to be fun. Students like to engage to such activities that is suitable for their age so they could absorb anything quickly especially in learning activity. Based on this research, storytelling gave so many advantages in teaching English to early childhood education students, this activity is suitable for very young learners and it could be done by teachers in their teaching activities. For the next researcher, the further research related to teaching English for early childhood education is needed especially to improve teacher's English ability since most of early childhood education teachers are not graduated from English department.

\section{References}

Blackledge A.Creese A. (2010). Multilingualism: A Critical Perspective. London: Continuum.

Harmer, J. (2007). How to teach English. Essex, England: Pearson Education Limited.

Kamil, M., \& Hiebert, E. (2005). Teaching and learning vocabulary: Perspectives and persistent issues. In E. H. Hiebert and M. L. Kamil (Eds.), Teaching and learning vocabulary: Bringing research to practice (pp. 1-23). Mahwah, NJ: Lawrence Erlbaum. Retrieved August 18, 2009, from PsycINFO database

Martin Chang, S. Y., \& Gould, O. N. (2008). Revisiting print exposure: Exploring differential links to vocabulary, comprehension and reading rate. Journal of Research in Reading, 31, 273-284.

Stahl, S. A., \& Nagy, W. (2005). Teaching Word Meaning. New Jersey: Lawrence Erlbaum Associates.

Stahl, S. A., \& Nagy, W. (2006). Teaching Word Meanings. New Jersey: Lawrence Erlbaum Associates.

Thornbury, Scott. 2002. How to Teach Vocabulary. Pearson Education Limited.

Zhang, L. J., \& Anual, S. B. (2008). The role of vocabulary in reading comprehension: The case of secondary school students learning English in Singapore. RELC Journal, 39(1), 51-76.

https://www.english.bimba-aiueo.com/kenapa-perlu-belajarvocabulary-dahulu/ https://www.researchgate.net/

https://www.thoughtco.com/purposive-sampling-3026727/ 